\title{
EDUCAÇÃO COMO AUTOCONSTITUIÇÃO \\ DO SER HUMANO: UMA ABORDAGEM FENOMENOLÓGICO-EXISTENCIAL*
}

Marcos Aurélio Fernandes**

\section{RESUMO}

Ao perguntar pelo ser da educação, investiga-se a educação enquanto fenômeno constitutivo essencial da existência humana. Expõe-se educação como autoconstituição e re-constituição do ser humano; como concreção da dinâmica da liberdade, que é a dinâmica do poder-ser, ou seja, da possibilidade e impossibilidade, do empenho e da gratuidade, em que está em jogo a passagem da impropriedade à propriedade da existência, numa palavra, a auto-invenção do "homem humano". A partir desta compreensão, por fim, pergunta-se que sentido tem a educação do outro, bem como toda a pretensão em que se funda a pedagogia.

Palavras-chave: educação; existência; liberdade; possibilidade; constituição; propriedade; pedagogia.

\section{Perguntando pelo óbvio}

Comecemos colocando a pergunta: o que é mesmo educação? Todos nós pressupomos já saber o que seja educação. E este saber pressuposto já atua, operativamente, em todos os nossos empenhos pela coisa $^{1}$, isto é, pela causa, pelo interesse, pela questão, da educação quer estes empenhos se dêem nos âmbitos educativos da família, das comunidades, da sociedade, quer se dêem nos âmbitos educativos das escolas, com seus afazeres pedagógicos; quer, ainda, aconteçam no âmbito acadêmico, onde se tematiza o fenômeno da educação, como

\footnotetext{
* Artigo recebido em 27/1/2007 e aprovado em 21/5/2007.

** Doutor em Filosofia pelo Pontifício Ateneu Antonianum de Roma e diretor da Escola Paroquial Santo Antônio, Brasília-DF. E-mail: framarcosaurelio@hotmail.com
} 
todo um campo de pesquisa científica, um campo já aberto como região disponível para conceituações, definições e sistematizações teoréticas, bem como para aplicações práticas.

Nós perguntamos, aqui, pelo ser da educação. Perguntar pelo ser da educação significa buscar e querer captar o vigor que deixa e faz ser a educação como educação, a vigência que inaugura, institui e rege a educação no que ela tem de mais próprio e originário.

\section{RECORDANDO O ÓBVIO: ONDE O SER HUMANO ACONTECE, ALI ACONTECE EDUCAÇÃO. A EDUCAÇÃO COMO AUTOCONSTITUIÇÃO DO HUMANO}

A nossa tese é a de que a educação é, antes de tudo, um fenômeno essencial da existência humana. ${ }^{2}$ Com isso, não queremos dar uma definição cabal do que seja educação, mas apenas definir o horizonte, a partir donde se pode captar a sua essência. De fato, falamos de educação, propriamente, somente ali onde está em jogo o abrir, o surgir, o desabrochar, o constituir-se da existência humana. As coisas não se educam, as plantas e os animais também não. O ser humano é que está em jogo, quando se trata de educação. Onde o ser humano acontece, em seu caminho de essencialização, ali acontece a educação.

Se a educação é um fenômeno fundamental do constituir-se e do con-crescer da existência humana, então é algo que diz respeito ao ser humano como um todo e a todo o ser humano como tal.

O fenômeno da educação é, pois, constitutivo do ser humano. É que o ser humano só se torna, efetivamente, humano, isto é, ele só vem a ser o que ele é através do empenho de sua liberdade. Neste sentido, nada há no ser humano que não precise ser assumido como uma tarefa de responsabilização pelo seu próprio ser, mesmo aquilo que nele parece o mais natural e dado por si mesmo, como caminhar, comer, beber etc. ${ }^{3}$ Nesse sentido, o caráter educativo está presente em todo ato humano, isto é, em todo comportamento, pois em todo comportamento o ser humano cunha a si mesmo como um ser de liberdade.

A educação é, portanto, aquele acontecer através do qual o ser humano se constitui a si mesmo. Por isto, o processo educativo diz respeito a todo o ser humano e ao ser humano como um todo. Seria, pois, um olhar superficial aquele que encarasse a educação como um fenômeno parcial da existência humana. A educação, neste sentido, precisa ser vista a partir daquela dimensão em que ela aparece na 
existência, ou seja, a partir da dimensão de profundidade da vida. ${ }^{4}$ Educação não é, pois, algo que acontece com o ser humano dentro de sua vida, neste ou aquele âmbito, neste ou naquele momento. Educação, antes, é $o$ acontecer mesmo do ser humano e de sua vida, o modo de seu vir à luz, do surgir de sua própria essência e identidade. Por isso, não existe lugar nem tempo marcado para educação. A educação se dá em todo o tempo e em todo o lugar, à medida que, por toda a parte e em qualquer momento, está em jogo o acontecer mesmo da vida. Por isso, a falta da educação só pode ser sentida como o não cumprimento e o não deslanche da essencialização do humano, aqui ou ali, agora ou em outro tempo. Por conseguinte, há diferentes tipos de educação, em diferentes contextos humanos: na família, educação familiar; na profissão, educação profissional; na política, educação política; na arte, educação artística; na religião, educação religiosa; e assim por diante. A escola é, portanto, apenas uma instância em que se dá a educação e sua pedagogia apenas um modo de se realizar o processo educativo, dando forma ao caráter pedagógico, inerente a todo o comportamento humano, nas mais diversas dimensões do viver. ${ }^{5}$

\section{A EDUCAÇÃO É SEM PORQUÊ: UM EVENTO INÚTIL, ISTO É, GRATUITO.}

Se partirmos do pressuposto de que a educação pertence ao todo do ser humano e não a uma parte, então se pode afirmar que $a$ educação não tem um fim, um objetivo, um para quê. É o desabrochar do ser humano como um todo, na responsabilização de seus empenhos e desempenhos. Esta responsabilização é que coloca fins, objetivos, metas. Contudo, ela mesma, no seu sentido, no vigor de seu desabrochar não tem um objetivo, um fim, uma meta.

A educação é sem porquê nem para quê, ou seja, é um fenômeno, que acontece desde o fundo de si mesmo, por acontecer. Como a Rosa, cantada pelo poeta-místico Angelus Silesius (Silesius, 1992, p. 156):

A rosa é sem por quê, floresce por florescer, não vê a si mesma, nem pergunta se alguém a vê. 
Considerar, pois, a educação desde uma perspectiva pragmatista, utilitarista, é um contra-senso. Como tudo aquilo que é fundamental e absoluto na existência humana, a educação não pode ser medida e avaliada a partir de suas possibilidades de instrumentalização. Talvez, se pudesse ousar dizer que com a educação nós não podemos fazer nada, mas isto não significa que a educação não possa fazer tudo conosco.

Tudo isto quer dizer que a educação só pode ser vista a partir dela mesma e de suas possibilidades mais próprias, íntimas e essenciais. Tais possibilidades dizem respeito, por sua vez, à necessidade da liberdade $\mathrm{e}$ da verdade para o surgimento da identidade do ser humano. Somente se deixando iluminar pela luz da verdade, o ser humano alcança sua liberdade. A educação não tem nenhuma causa, ela acontece por si mesma e desde si mesma, ali onde o ser humano cunha sua própria identidade através da verdade e da liberdade. A educação não tem nenhuma utilidade. E é nisso que reside a sua importância primordial: ela não é importante e necessária por causa disso ou daquilo, mas por causa de si mesma. Ela é tão necessária quanto é necessário ao humano o empenho pela liberdade através da verdade e pela verdade através da liberdade. ${ }^{6}$ Disto nos fala um poeta grego da época contemporânea (18591943), Kostis Palamás (apud LEÃo, 1990, p. 20):

A verdade não é para escravos. O escravo já renunciou à liberdade da verdade, ao escolher o poder, a riqueza ou a fama para amo e senhor. A verdade é daqueles que nunca cessam de libertar-se da escravidão para a liberdade de uma verdade redentora.

A educação acontece, por conseguinte, a partir de si mesma, no próprio movimento histórico em que o ser humano, no empenho pela liberdade através da verdade e pela verdade através da liberdade, se configura, cada vez de modo diverso, nas diferentes épocas. O tempo, no sentido de epocalidade, ministra, pois, a cada vez, as necessidades e as tarefas concretas com que o ser humano tem que se haver e, por conseguinte, as necessidades e as tarefas concretas da educação do ser humano em uma determinada época. A educação é, neste sentido, sempre e cada vez, uma responsabilização histórica do ser humano, uma responsabilização pela constituição de si mesmo, através da verdade e da liberdade, responsabilização que se exerce, a cada vez de modo singular, na singularidade de épocas diferenciadas. 
A educação diz respeito, portanto, a todo ser humano e ao ser humano todo, nas mais diversas épocas, com suas necessidades e tarefas. Ademais, a educação diz respeito a todas as etapas da vida humana, do nascimento à morte. Aliás, é importante perceber que as diversas etapas da vida não podem ser hierarquizadas. Cada etapa encerra em si, de maneira cada vez peculiar, um sentido pleno de autoconstituição do ser humano. Assim, a infância e a juventude não podem ser vistas a partir da perspectiva do ser humano adulto. Cada etapa da vida tem a sua plenitude própria e a cada etapa, com suas continuidades e rupturas, são inerentes a determinadas necessidades e tarefas.

A LIBERDADE É O PRINCÍPIO DA EDUCAÇÃO. LIBERDADE COMO DINÂMICA DO PODER-SER

A educação é, pois, um acontecer, cujos processos pressupõem a conquista e a afirmação cada vez mais decidida da autonomia do ser humano. Autonomia, aqui, porém, não é entendida somente como a liberdade negativa, ou seja, a independência, emancipação e autosuficiência, nem somente como a liberdade positiva, ou seja, a vinculação através dos compromissos e responsabilizações, mas, sobretudo, como a liberdade originária, aquela através da qual o ser humano constitui a si mesmo. A liberdade é o princípio decisivo da educação. Toda educação ou é para a liberdade ou não é educação. A liberdade, porém, só acontece ali onde o ser humano realiza o seu poder-ser mais próprio e originário, ou seja, ali onde ele se torna aquilo que, por essência e desde o fundo de si mesmo, é chamado a ser. A liberdade, por conseguinte, não é algo que o homem tem, dado de modo puro e simples, mas a liberdade é uma convocação que urge a resposta do ser humano, um apelo para vir a ser propriedade de si mesmo, um chamado para o seu ser mais próprio, para a sua vida mais plena. Como nos testemunha um dito de Fichte (apud Buzzi, 1998, p. 100):

O homem não pode ser herdado, nem vendido nem tampouco presenteado. $\mathrm{O}$ homem não pode ser propriedade de ninguém, porque ele é e deve permanecer propriedade de si mesmo. Ele carrega no fundo de si mesmo uma chama divina, a consciência moral, que o eleva sobre a animalidade, tornando-o cidadão de um mundo cujo primeiro parceiro é Deus. Essa consciência lhe possibilita querer isso 
ou não querer aquilo de maneira incondicional, livre e a partir de seu próprio movimento, sem nenhuma pressão exterior.

Educação é, fundamentalmente, um afazer, um por fazer, uma tarefa. Trata-se da tarefa de perfazer, de constituir o nosso próprio ser, de chegarmos a ser propriedade de nós mesmos. É responder e corresponder à convocação de ser, de ser si mesmo, de vir a ser o que somos. A educação responde ao apelo, que ressoa na segunda Ode Pítia, de Píndaro: "vem a ser, na própria experiência, aquele que tu és" (apud SchUBACK, 1998, p. 193). Isto quer dizer: "vem a ser o que tu podes ser". $\mathrm{O}$ poder-ser é aquele lance no qual eu sou entregue à minha própria responsabilidade de ser. ${ }^{7}$ É o envio do destino da liberdade. ${ }^{8}$ É o imporse da necessidade de ser. De fato, na dinâmica concreta da liberdade, uma possibilidade só é viável e promissora quando se torna para o humano a única e incomparável, como recorda o poeta Rilke a um jovem que se aconselhara com ele a respeito de sua aptidão ou não para poder ser poeta (RILKE, 2004, p. 26-27):

Pergunta se os seus versos são bons. Pergunta-o a mim, depois de o ter perguntado a outras pessoas. Manda-os a periódicos, compara-os com outras poesias e inquieta-se quando suas tentativas são recusadas por um ou outro redator. Pois bem - usando da licença que me deu de aconselhá-lo -, peço-lhe que deixe tudo isso. O senhor está olhando para fora, e é justamente o que menos deveria fazer neste momento. Ninguém o pode aconselhar ou ajudar - ninguém. Não há senão um caminho. Procure entrar em si mesmo. Investigue o motivo que o manda escrever; examine se estende suas raízes pelos recantos mais profundos de sua alma; confesse a si mesmo: morreria, se lhe fosse vedado escrever? Isto, acima de tudo, pergunte a si mesmo na hora mais tranqüila de sua noite: 'sou mesmo forçado a escrever?'. Escave dentro de si uma resposta profunda. Se for afirmativa, se puder contestar àquela pergunta severa por um forte e simples 'sou', então construa a sua vida de acordo com essa necessidade. Sua vida, até em sua hora mais indiferente e anódina, deverá tornar-se o sinal e o testemunho de tal pressão.

Por tudo isso, o humano ainda não é livre só por poder escolher isso ou aquilo. A escolha é uma condição necessária, mas não ainda suficiente para que a liberdade aconteça. O ser humano é livre somente quando escolhe o que para ele se tornou a única e incomparável possi- 
bilidade, vale dizer, o que se lhe tornou uma necessidade da sua própria liberdade. Com efeito, o meu ser mais próprio é liberado como aquele que surge da minha única possibilidade real, ou seja, da minha mais radical necessidade livre. Eu tenho de ser o meu próprio ser, isto é, o meu ser mais próprio. O humano é, cada vez, obra da possibilidade deste poder-ser, que é, ao mesmo tempo, ter-que-ser, ou seja, desta possibilidade, que é, simultaneamente, necessidade, envio, história, destino. ${ }^{9}$

O que o humano alcança de mais originário e próprio depende, sempre, de sua vontade de poder, que é, em sentido mais pleno e próprio, a vontade de poder-ser, ou seja, o empenho de querer, onde está em jogo não simplesmente o querer isto ou aquilo, mas, antes de tudo, onde está em jogo, em todo o querer isto ou aquilo, em última instância, o querer o querer de seu próprio querer. ${ }^{10}$ Como declara Nietzsche (apud HeIDEGGer, 1998, p. 305):

“IMPRIMIR AO DEVIR O CARÁTER DO SER - É ESTA A SUPREMA VONTADE DE PODER".

O ser me foi entregue como dom, mas, ao mesmo tempo, como tarefa de uma responsabilização. Por isso, o ser, que sou, precisa ser, sempre de novo, assumido e realizado no meu devir. E o meu devir precisa, sempre de novo, ser configurado de tal modo que, nele, possa ir aparecendo a figura, a imagem, a expressão mais plena do meu ser mais próprio (FoGEL, 1998, p. 177-178):

"Vem a ser o que tu és" diz, possibilidade: constitui-te na tua necessidade - no teu destino. Tem, sê destino - o teu destino. Este movimento de envio e reenvio de $\mathrm{si}(=$ possibilidade $=$ destino $)$ para si mesmo $(=$ possibilidade $=$ destino $)$ configura a exposição do 'próprio', que é, então, a dinâmica de concretização ou de realização da liberdade. Liberdade como o movimento, como a dinâmica de exposição e de liberação da necessidade, isto é, do "próprio". Este processo de envio e de reenvio da possibilidade, respectivamente necessidade dela mesma, vai traçando, na repetição e na recuperação, isto é, no retorno e na retomada dela para e por ela mesma, o perfil do programa, do projeto de ser - de ser isto que se é. É repetição, retomada, isto é, insistente retorno e, assim, e por isto mesmo, projeto, 
projeção. Porque é o sempre já desde onde emerge, a possibilidade é passado, o passado originário-originante; porque é o para onde se está sempre já lançado (projeto), por isso, é a possibilidade sempre já futuro. E este passado e este futuro se abrem, se insinuam sempre e só num "hic et nunc" da minha vida, da minha existência concreta, isto é, na minha situação, enfim, no meu presente.

A vontade de poder, enquanto vontade de poder-ser, não quer excluir nada de sua possibilidade, e, por conseguinte, de sua responsabilidade. Quer se pôr a si mesma de uma maneira tão autônoma, que quer assimilar até mesmo a sua impossibilidade, o inevitável, o inexorável, o incontornável, como nos declara Nietzsche (apud BuzzI, 1998, p. 88):

Faço ferver em minha marmita tudo o que é acaso. E somente quando o acaso está no ponto, eu lhe desejo boas-vindas para com ele fazer minha alimentação. E, na verdade, muito acaso se aproximou de mim imperiosamente ainda e logo ele estava de joelhos diante de mim e me suplicava - suplicava que the desse asilo e acolhida cordial, e me falava de maneira aduladora: veja, então, Zaratustra, só um amigo vem assim a um amigo.

Contudo, o querer, que quer o querer de seu querer, ou seja, o querer que quer sua suprema liberdade, ainda não é bastante livre. Em virtude de sua própria dinâmica, a liberdade não é, por um lado, um processo que acontece sem empenho, mas também não é, por outro lado, um processo que acontece unicamente por força do empenho da vontade humana. $\mathrm{O}$ acontecer da liberdade é dom de uma conquista: é empenho da vontade humana, que é chamada a se tornar, em cada nova vicissitude da vida, uma boa-vontade; mas é também evento da gratuidade do mistério da vida, que presenteia o ser humano e premia seus empenhos com cada vez novas irrupções de sua benignidade. Para entender melhor isso, vamos recorrer a uma estória exemplar (HARADA, 2006, p. 311-312):

Conta uma lenda japonesa que o famoso guerreiro do antigo Japão, Kussunoki Massashige, celebérrimo pela sua inteligência e pelos seus lances geniais de estratégia, já na sua infância vivia no meio dos guerreiros. Uma vez, no castelo do seu pai, observava os guerreiros que, reunidos ao redor de um enorme sino de bronze suspenso por uma armação de grossas madeiras, estavam apostando quem deles conseguiria pôr em movimento o sino, que pesava toneladas. Mas 
nenhum deles, nem mesmo os mais hercúleos, conseguia mover o sino por um milímetro sequer, por mais ímpeto e violência que empregasse. $\mathrm{O}$ menino assistia a tudo isso com muito interesse. De repente, oferece-se para mover o sino, e lhes pergunta se pode usar todo o tempo de que necessita para tal empreendimento. Meio zombeteiros, meio admirados, mas achando graça, os guerreiros desafiam-no a realizar o seu propósito. O menino cola todo o seu corpo ao sino e, sem pressa, sem ânsia, suavemente, mas com toda a possibilidade de seu pequenino corpo, empenha-se corpo a corpo, ele todo e inteiro, a empurrar o sino com o seu exíguo e finito corpo até onde pode e solta, empurra e solta, como que sondando o tempo do sino, cordialmente, sempre de novo e sempre novo; como que recebendo e dando parte do sino e parte de si, numa simbiose, num intercâmbio amigo, por horas a fio. E pouco a pouco, de início imperceptivelmente, mas depois visivelmente, o enorme sino começa a balançar.

Contudo, o que esta estória tem a ver com a vontade de poder-ser e com a dinâmica da liberdade, que é, ao mesmo tempo, empenho e dom, possibilidade (necessidade) e impossibilidade?

Doar-se cordialmente, corpo a corpo, todo e inteiro no empenho humilde de tentar mover o impossível não é mais a atitude de querer poder subjugar o impossível. Não é também a atitude de se entregar à impossibilidade, como quem é dominado e subjugado contra a vontade, digamos, resignado. É, antes, uma atitude na qual o homem se dispõe a deixar-se embalar pela força que o transcende, sendo carregado por ela, fluindo nela. Em se doando como possibilidade finita todo e inteiro à impossibilidade, o menino recebe a sua própria finitude de volta, fluindo na dinâmica abissal do que não pode. Dinâmica abissal em que, para dentro e a partir da qual, a possibilidade finita se alça, se ergue, toma pé como a criatividade, toma pé como a criatividade disposta de ser e deixar ser. O sino não é inimigo. Não é paredão do contra. É o maior, o imenso. O grande. É impossibilidade, não como exclusão da minha possibilidade, mas sim como a possibilidade anterior, infinita, que permite, me dá a possibilidade alegre da finitude agraciada. A “im-possibilidade” não é negação da possibilidade. É, antes lá, onde a possibilidade finita nada como peixe na imensidão do mar. (HARADA, 2006, p. 313) 
Cada nova conquista de liberdade, cada novo dom do "amadurecimento" do ser humano, é algo como um novo nascimento, uma retomada da vida, desde o fundo de si mesma, na sua originariedade, e um acontecer de sua plenificação. É um alcançar aquilo que nos é o mais próximo e, que por isto mesmo, nos parece o mais distante: o ser que nós mesmos somos e que, sempre de novo, somos chamados a ser.

EDUCAÇÃO COMO RETORNO DA IMPROPRIEDADE À PROPRIEDADE DA EXISTÊNCIA, ATRAVÉS DA POSSIBILIDADE E DA IMPOSSIBILIDADE DA LIBERDADE

Liberdade é justamente o processo de crescimento na cordialidade da dis-posição para deixar-ser e emergir a verdade de si mesmo, é o processo de liberação do mais próprio de si. Liberar significa, aqui, destrancar e desbloquear, no sentido de abrir espaço, dispor para o deslanche, deixar irromper o único necessário.

Como, de início e na maioria das vezes, o ser humano já fugiu de sua convocação de ser e, nesta fuga, alienou-se e bloqueou para si mesmo as possibilidades de uma vida em plenitude, a educação é sempre uma tarefa de retorno do ser humano para a sua origem, de saída de sua alienação e de guinada de uma existência imprópria para uma existência própria. Educação não é outra coisa, pois, do que a reconstituição do humano da impropriedade para a propriedade do ser. A autoconstituição do ser humano é, portanto, sempre, uma espécie de re-constituição.

A educação se dá, por conseguinte, no caminho do ser humano para si mesmo, no seu retorno para a sua origem, a qual se localiza ali onde ele possa "se sentir em casa", ou seja, ali onde ele possa encontrar a sua mais plena realização. A tarefa da educação é, por conseguinte, a tarefa do reencontro do ser humano consigo mesmo e com sua origem, é a tarefa do resgate de sua dignidade esquecida e da reconstituição de sua identidade e integridade originárias. Como nos testemunham as Confissões, de Agostinho, o homem é, desde o fundo de si mesmo, sempre de novo, chamado de volta de seus subterfúgios, para entrar na existência, inserir-se nela. O ser humano é algo assim como um rei destronado, que de-caiu de sua dignidade e que dela se esqueceu, e que passou a vagar errante, longe de seu "reino" e de sua "terra natal". É preciso que ele, de alguma maneira, mergulhado na miséria de sua existência, "caia em si", 
dê-se conta de sua auto-alienação, de sua errância e perdição, para, então, como que num "despertar", acorde para a necessidade do retorno, do giro para o seu mais próprio, da conquista do que já sempre foi, da "recuperação" de seu trono e de seu reino.

Evasão e retorno constituem, pois, o duplo movimento do existir humano, na dinâmica da liberdade. Ser humano é já sempre ter fugido de si, do ser mais próprio e originário, mas é, também, a possibilidade e a necessidade, a provocação e a convocação de estar a caminho de si mesmo. O primordial ser distanciado de si mesmo aparece, para o humano, como culpa, entendendo-se esta categoria no sentido existencialontológico e não tanto no sentido moral. Mas é daí, desta exigência fundamental, a saber, da exigência de que o homem assuma seu próprio ser e empenhe-se em realizá-lo, que surge o modo de ser do ético e da ética. Falar de ética é falar desta tarefa de autoconstituição do ser humano, como tal. É recordar que o humano, em todo o seu fazer ou deixar de fazer, em todo o seu agir, e em todo o seu criar, está sempre em jogo, como aquele que deve, através da dinâmica da liberdade, encontrar-se a si mesmo, inventar-se a si mesmo, como o humano que é. Tudo, para o humano, é chance e ocasião desta auto-invenção. Também e, talvez, sobretudo, as situações de limitação, fragilidade, pobreza, impossibilidade. O humano traz em si a centelha da liberdade, e isso permanece intocado pelo tempo e pelo espaço. Em toda a parte e em cada momento, mesmo, e talvez, antes de tudo, naquelas situações de maior impossibilidade, o humano pode acender aquela chama. De fato, do não-poder faz-se a faísca do poder-ser. Não, certamente, não através da superação ou da eliminação das dificuldades e da impossibilidade, mas, antes, justamente através da aceitação das dificuldades e do empenho cordial de obediência/ausculta da impossibilidade mesma, como de uma imensidão e profundidade maior do abismo da vida, em sua gratuidade. Por isso, podemos dizer: não aquilo que nós podemos nos torna livres, mas aquilo que nós não podemos. Na irrupção gratuita da liberdade, o impossível se torna possível, mas o caráter de ser deste possível constitui-se de uma possibilidade que é, ao mesmo tempo, necessidade. Somente ali onde o impossível se transforma em possível é que há verdadeiro ser capaz e verdadeiro empenho humano. O impossível é a possibilidade do Si mesmo, o meramente possível, sua impossibilidade. O acolhimento da impossibilidade e do limite é o retorno do mero poder ao verdadeiro 
poder-ser, é o empenho e a graça da libertação, como nos conta uma estória monástica:

De certa feita, um jovem entrou para um mosteiro a fim de alcançar a libertação pelos rigores do claustro e pela disciplina da meditação. $\mathrm{O}$ mestre saiu para o pátio, apanhou um caco de telha e se pôs a esfregálo numa pedra de esmeril. Passou dias inteiros concentrado no esforço de esmerilar a argila. $\mathrm{O}$ recém-chegado se aproximou e indagou o que o monge pretendia com todo aquele trabalho. O monge respondeu que, raspando com todo o cuidado, ia transformar o caco de telha num espelho. O noviço retrucou: então, pode desistir. Caco de telha, por mais que se raspe, não vira espelho. $\mathrm{O}$ monge comentou apenas: pensei que você não sabia. Como não, disse o jovem. Todo o mundo sabe que espelho é metal e não barro. O monge concluiu: libertação também não é esforço de meditação. (LEÃo, 1990, p. 21)

O regresso do mero poder ao poder ser - que é cordialidade que deixa ser a gratuidade do dom da liberdade na impossibilidade - o próprio limite constitui o processo de encarnação do humano. Dá-se a encarnação do humano quando, neste processo de libertação do poder-ser através do não-poder, uma existência, inteiramente, sem nada excluir de si, entra nos limites de seu existir, se insere em sua própria carne. Encarnação é retorno da alienação, é o encontrar-se a si mesmo no seu lugar essencial, é o "ad-sum", o "eis-me aqui", através do qual a existência humana se torna uma pre-sença (Da-sein) própria e originária. ${ }^{11}$

No retorno, alguém encontra aquilo que ele é. A sua vida lhe é dada como sua possibilidade. Liberdade, portanto. A liberdade para todos. E é para ninguém. É para todos, à medida que a todos é dada como dom e como tarefa. É para ninguém, à medida que este dom só é recebido e esta tarefa só é cumprida, quando cada qual, na singularidade de sua historicidade, chega à existência na sua propriedade, ou seja, torna-se presença na comunhão de tudo e na comunhão com todos. Quem chega a isso torna-se, de fato, o homem humano, que já era. A este, nada do que é humano lhe é estranho. Ele mergulhou suas raízes na terra dos humanos, onde estes nascem, crescem e morrem, como humanos: a terra de sua própria mortalidade e finitude, o húmus do não-poder, a partir donde floresce e viceja a flor do poder-ser. Ele vive firme e fluente no vigor da humildade. 
EDUCAÇÃO COMO AUTO-INVENÇÃO DO HUMANO. QUE SENTIDO TEM UMA PEDAGOGIA?

A liberdade existencial somente brota a partir do infinito esforço de trabalhar a si mesmo, inserindo-se em todas as finitudes humanas, obedecendo à necessidade incondicional da tarefa de ser o mais próprio de si mesmo. Encarnação é auto-invenção. É o difícil trabalho da transformação interior. A educação, se pensada nesta dinâmica da autoinvenção humana, não é meramente o processo de busca do conhecer, pois a busca do conhecer nos permite permanecer alheios a nós próprios e à nossa tarefa de essencialização humana, como nos alerta Carneiro Leão (apud ScHUBACK, 1999, p. 247):

Quando se deseja conhecer, não é preciso mudar muita coisa no que se é. Precisa-se apenas adquirir um conjunto de habilidades, de informações, de regras, de modos de proceder, de meios de demarcação e de material. Deve-se ainda desenvolver uma grande habilidade em colher, subsumir, calcular relações, em testar e procurar fortificar padrões de correspondência e interpolação...

Não é necessário transformar-se para conhecer, pois é no nível e com o modelo do que já se sabe que se aumenta o acervo do conhecimento. O ser de quem conhece pode permanecer o mesmo ser antes e depois de ter conhecido, sem que com isso se inviabilize o conhecimento...

Por isso, por não forçar uma mudança no modo de ser, o conhecimento pode ser claro, distinto, preciso, eficaz, operativo.

A educação, pensada na dinâmica da auto-invenção humana é, antes, o processo do "pensamento do silêncio", que é, em última instância, busca do ser (Leão apud SchUBaCK, 1999, p. 248-249) :

Outro é o modo de ser, o estatuto do pensamento do silêncio. Para pensar no silêncio não ajuda muito tudo o que se possa saber, que se possa conhecer, que se possa fazer, pois, quando se chega a saber, conhecer ou fazer alguma coisa, o processo de pensar já se instalou, já se consolidou nos níveis e nos recursos de suas mudanças e transformações...

A fim de compreender o pensamento do silêncio urge uma outra qualidade de ser, impõe-se uma outra índole de leitura dos fenômenos, 
exige-se um outro nível de realização diferentes da compreensão e do conhecimento a serviço da operação e da transformação. Tudo isso requer e demanda uma paciência estranha, aquela paciência de que fala o fragmento 18 de Heráclito, nas palavras: "A espera do inesperado é condição para se ter a possibilidade de encontra-lo".

Ora, como transformar-se é penoso, como esperar o inesperado angustia, como crescer dá trabalho, e amadurecer traz dor e sofrimento, naturalmente é o silêncio do pensamento que é obscuro, confuso, enigmático, difícil de compreender. Quando se está aquém do nível em que o pensamento se move, o silêncio não pode ser compreendido e, por isso, a sua contribuição e o seu advento é sempre obscuro, um obstáculo. Esta experiência do silêncio marca uma disposição de abrirse, de estar continuamente disponível para as transformações de padrões de comportamento e das forças instauradoras das estruturas de expectativas.

A auto-invenção do humano, sua individuação e encarnação, só acontece com dores. A alienação tem boa consciência. Nela, fugindo-se de si, ambiciona-se os mais preciosos objetivos. Quanto mais o humano se apressa em sua ambição pelos objetivos mais distantes, tanto mais se torna perigosa a reconstituição e a encarnação. Não se escuta a voz interior, que é um chamado, a assumir aquele lugar único no meio da vida, que está destinado a cada um em sua singularidade e unicidade.

A liberdade consiste na constituição e total reconstituição do próprio, é o evento do instaurar-se da singularidade, que é, ao mesmo tempo, universalidade, uma vez que o ser um, buscado e alcançada na dinâmica da liberdade, é também um ser um com tudo e com todos. Liberdade é a meta do um trabalho da vida; é o alcance de uma estrutura da vida; é o "próprio" em sua total concreção.

Se o sentido da educação é a liberdade, e esta se realiza como a dinâmica do processo de autoconstituição e re-constituição do humano, na passagem da impropriedade à propriedade da existência; se o sentido da educação é a liberdade, que é processo de encarnação e de limitação, de essencialização e individuação humana, enfim, caminho de plena realização do próprio, de alcance da plenitude da vida; então, que sentido tem toda a pedagogia no processo da educação?

De fato, esta pergunta faz sentido. Pois, não se pode conduzir ninguém a ser ele mesmo, na sua mais plena e própria possibilidade e necessidade de ser. Nós podemos dar uns aos outros muitas coisas, mas 
não podemos dar ao outro a disposição de receber. Na relação de dar e receber, cada qual deve já sempre receber do outro a possibilidade de dar, pois cada um que recebe, dá, antes de tudo, a possibilidade de receber. E isso ele o faz a partir de sua mais própria liberdade. No fundo, não se pode ensinar o próprio a ninguém. Não se pode nem mesmo indicá-lo. Aqui, é impossível pensar num "mestre". O trabalho da liberdade só é executável através dele mesmo. Disto nos recorda uma velha estória chinesa, contada pelo sábio Chuang Tzu:

O Duque Hwan, de Khi, o primeiro da dinastia, sentou-se sob o pálio lendo filosofia; e Phien, o carpinteiro de rodas, estava fora, no pátio, fabricando uma roda. Phien pôs de lado o martelo e a entalhadeira, subiu os degraus, disse ao Duque Hwan: "permiti-me perguntar-vos, senhor, o que estais lendo?" Disse-lhe o Duque: "os peritos. As autoridades". E Phien perguntou-lhe: "vivos ou mortos?" "Mortos há muito tempo". "Então", disse o fabricante de rodas, "estais lendo apenas o pó que deixaram atrás." Respondeu o Duque: "O que sabes a seu respeito? És apenas um fabricante de rodas. Seria melhor que me desses uma boa explicação, senão morrerás." Disse o fabricante: "Vamos olhar o assunto do meu ponto de vista. Quando fabrico rodas, se vou com calma, elas caem, se vou com muita violência, elas não se ajustam. Se não vou nem com muita calma, nem com muita violência elas se adaptam bem. $O$ trabalho é aquilo que eu quero que ele seja. Isto não podeis transpor em palavras: tendes apenas de saber como se faz. Nem mesmo posso dizer a meu filho exatamente como é feito, e o meu filho não pode aprender de mim. Então, aqui estou, com setenta anos, fabricando rodas, ainda! Os homens antigos levaram tudo o que sabiam para o túmulo. E assim, senhor, o que ledes é apenas o pó que deixaram atrás de si”. (Apud Merton, 2002, p. 128-130)

Aqui, parece que toda a educação é fadada ao fracasso. Apresentase a impossibilidade de ensinar e aprender, no convívio humano, em que está sempre em jogo a liberdade, não só a de dar e receber um ao outro, mas também e sobretudo a liberdade de ser!

Educação só tem sentido ali onde há a necessidade da coragem de ser o próprio de si mesmo. Esta coragem supõe que cada um possa deixar acender a chama, a centelha, da verdade, que traz em si mesmo. Supõe que se alguém possa se tornar capaz de ver, na sombra, a luz; na indisponibilidade, a capacidade; na limitação, a liberdade. Pode, no entanto, 
alguém ajudar o outro a ser ele mesmo, a tornar-se capaz de sua mais própria possibilidade de ser?

A educação, enquanto autoconstituição do ser humano, só acontece, de fato, ali onde se dá a relação entre ser humano e ser humano. A educação é algo que se realiza, justamente, no "entre" das relações inter-humanas. É que nós só nos tornamos nós mesmos, quando assumimos plenamente o nosso ser-no-mundo e o nosso ser-com-os-outros. A educação é uma tarefa de fazer surgir o eu do mundo do nós e para o mundo do nós, na relação com o tu, com o vós. Ela acontece a partir do fato de sermos participantes de um mesmo mundo e, nesta participação, a partir do fato de sermos abertos uns para os outros e abertos para a totalidade do real. Por isto, a educação requer, antes de tudo, um sentido de pertença ao mesmo. Surge uma comunidade educadora ali onde a educação de cada um, na sua singularidade, é assumida como o voltarse para uma causa comum, isto é, para o centro do interesse, a partir do qual aquela comunidade se constitui como um círculo de convivência. A educação, neste sentido, é o despertar para o apelo à coragem de ser, vale dizer, à coragem de ser um todo e à coragem de ser parte, de participar, de partilhar, de compartilhar.

Educação supõe, portanto, relação. O que quer dizer, entretanto, relação, neste contexto? Aqui, relação não significa algo de formal-vazio, mas sim algo de existencial. Sua essência fundamental é aproximar-sedo-outro, deixar-se-interessar-por ele, ser-interpelado-pelo-outro e interpelá-lo, um ser solicitado e solicitar, um responder e corresponder. Com outras palavras, é ser um tu para o outro e deixar que o outro seja um tu para mim. O que funda a educação é, pois, a solicitude ou preocupação com o outro. A educação se funda, portanto, na estrutura da "cura", ou seja, do cuidado. Ela só acontece de fato quando, na aprendizagem do conviver, somos empurrados para fora do domínio da indiferença e do mundo despersonalizado do "a gente" ou do "todo o mundo" e somos remetidos à tarefa de sermos nós mesmos por graça dos nossos encontros com os outros e de deixarmos os outros serem si mesmos por graça do encontro conosco.

Educar é o cuidado de tomar em consideração o outro no envio de sua possibilidade mais própria. É o cuidado de aproximar-se-do-outro, de deixar-se-interessar-por ele. Supõe a disposição de se deixar interpelar pelo outro e de interpelá-lo, em vista do seu poder-ser, de sua possibilidade mais própria. É solicitude pela encarnação e individuação do 
outro. É ajudar o outro a dar à luz o ser que ele já é. Por isso, todo o educador, na dinâmica do pensamento, é, como bem sabia Sócrates, não mãe ou pai daquele que ele educa, mas seu parteiro. O educador é alguém que está próximo, para testemunhar o ressoar daquela voz, que ecoa já sempre dentro de cada ser humano, e que o chama a vir a ser ele mesmo, na sua singularidade e propriedade. $O$ educador nada faz. Apenas deixa ser: deixa repousar nela mesma a obra da liberdade, que cada um, a custa de muito trabalho e a duras penas, gera e produz, a partir do fundo de si mesmo. O educador não pode libertar o outro. Só pode mesmo testemunhar ao outro a possibilidade da libertação de si. O educador não pode despertar o outro. Só pode mesmo deixar ressoar em si mesmo, como num amplificador, a voz que já ecoa no outro.

Uma tal pedagogia nada faz, nada exige. Não intervém, não calcula, não domina. Ela somente acompanha, segue, persegue, o outro, no seu caminho para o próprio. Ela apenas segue o movimento da vida mesma, que continuamente empurra o ser humano para a originalidade da singularidade, ou seja, para a originariedade de seu próprio. Ela apenas testemunha o nascimento do absoluto na limitação da finitude humana. Testemunha que educação é a autogênese do humano, a qual só acontece através do despertar para a coragem de ser, de ser na singularidade, de ser no poder-ser mais próprio e originário da existência.

\section{NOTAS}

1. Na fenomenologia, recorre-se ao slogan: "Zu den Sachen selbst!" - "Às coisas mesmas!”. Trata-se de uma provocação e convocação a não se deter em conceitos vagos, em enunciados sem evidência, em teorias construídas no ar, mas a se ater à "coisa mesma". A palavra "coisa", aqui, no entanto, não tem tanto o sentido de objeto temático de uma investigação predicativa (Objekt), nem de um objeto contraposto que emerge de e em uma experiência prépredicativa (Gegenstand), nem, ainda, de algo que está aí, disponível-para e vigorante-em o nosso uso, no cotidiano (Ding). A palavra "coisa" (Sache), significa, antes, a cousa, como o que está em causa, aquilo para que se volta o nosso foco e interesse, aquilo que está em questão, que promove e move o pensar. A "coisa" é, neste sentido, a solicitação e reivindicação da radicalidade, transparência e originariedade do pensar. A "coisa mesma" é a auto-evidência do que está em causa, a qual vai crescendo e se oferecendo, por si mesma e a partir de si mesma, à medida que o pensamento (lógos) vai deixando e fazendo ver o que se mostra em si mesmo (fenômeno). 
2. A reflexão que aqui segue só se tornou possível graças à leitura dos escritos do fenomenólogo alemão H. Rombach, aluno de Heidegger, que, dentre outros feitos, teve o mérito de aplicar e aperfeiçoar a fenomenologia ontológicoexistencial ao pensar a educação e a pedagogia (Cf. RомвACH, 1993, passim).

3. A palavra liberdade, aqui, como se dirá logo à frente, não há de ser entendida somente no seu sentido negativo, isto é, como ser-livre-de (independência), nem somente no seu sentido positivo, ou seja, como ser-livre-para (autonomia). Há que se entendê-la num sentido essencial. A essência da liberdade não está na arbitrariedade do querer; nem está na submissão a meras leis. A essência da liberdade tem a ver, antes, com a dinâmica pela qual o ser do ser humano está entregue à sua responsabilidade. Existir é, para o ser humano, ter que ser o próprio ser, ter sido atingido pela convocação de vir a ser o que ele é, ser alcançado pelo apelo de ser si mesmo e, assim, de se responsabilizar por tudo quanto, por meio de sua presença, de alguma maneira, vem a se mostrar como sendo.

4. A profundidade da vida, porém, só nos é acessível como o que se dá e, ao mesmo tempo, se subtrai, na superfície da mesma vida, em sua cotidianidade mediana. A dimensão de fundo só pode ser intuída como o sem fundo (o abismo) da própria existência em sua absoluta gratuidade (em seu ser sem porquê e sem para quê).

5. Aqui, ao falarmos de educação, vamos dirigir o nosso olhar para o fenômeno na sua amplidão, profundidade e originariedade, sem nos determos empiricamente no modo como este acontece no âmbito mais limitado da escola.

6. Entendemos a palavra "verdade", aqui, no sentido grego de Alétheia: revelação. Por sua vez, revelação é o mostrar-se do mistério como mistério. Isso quer dizer: há revelação ali onde o des-velamento assinala o velamento, o des-en-cobrimento insinua o en-cobrimento, o visível se recolhe no invisível, a luz na escuridão, a palavra no silêncio. O humano só se torna humano empenhando-se pelo des-velamento, pelo des-cobrimento. Como na tragédia de Édipo, ele precisa adquirir um "olho a mais", tornando-se apto a colher o ser ou na própria aparência ou contra a aparência, quer dizer, a surpreender o brilho e a claridade da alétheia (verdade) na dóksa ou contra a dóksa (glória, fama, mas também, opinião, parecer). No entanto, o humano não está submetido somente ao perigo de se deter numa glória sem consistência, numa fama sem justeza, num aparecer sem ser ou num parecer sem evidência. Há também o perigo de se deter no ser sem nada, no desvelamento sem velamento, no des-encobrimento sem en-cobrimento, na evidência meridiana sem o sentido da escuridão luminosa e da luminosidade escura do abismo. Então, acontece o que se passa conosco hoje: tudo brilha como luz de néon, numa clareza que açoita toda a penumbra do mistério. 
Então, o único mistério é o que já não há mais mistério: que tudo tenha se dado numa "verdade" plana, unidimensional, total e totalitária.

7. O já ter sido lançado na existência e incumbido da tarefa de ser constitui o que podemos chamar de facticidade da existência humana. O factum de já existirmos, de já nos encontrarmos "no meio desta vida", tendo que se haver com ela, no seu todo, sempre de novo e de modo novo a cada momento, não se dá como este ou aquele acontecimento dentro de nosso tempo e história, é, antes, o evento que instaura a temporalidade e a historicidade de nossa existência como um todo. Trata-se, portanto, de um passado sempre presente, que nos acompanha e nos antecede a todo o momento, desde o nascer até o morrer.

8. A existência humana é, enquanto experiência (Erfahrung), sempre, uma viagem (Fahren). O humano é homo viator: está sempre num en-vio, isto é, sempre em via, na destinação e no lance de um caminho. O humano está sempre a caminho - a caminho de quê? Não será: a caminho de si mesmo? Do seu mais próprio e originário ser? O que está em jogo, em nossa existência, não será, pois, um retorno ao que já sempre éramos: à nossa essência, à nossa possibilidade mais própria de ser? Aristóteles chamou à essência - a possibilidade mais própria e originária de ser de um ente, tó ti en einai, o que os latinos traduziram por quod quid erat esse - "aquele 'quê' que era ser". Dito de outro modo: a essência é aquele "quê" que cada ente é, enquanto sua possibilidade mais própria e originária. Tudo precisa se tornar o que já é. E, no mundo, tudo está, continuamente, vindo a ser o que já é. Neste sentido, de fato, "não existe nada de novo debaixo do sol", como repetia o sábio da Bíblia (Qoelet). As coisas estão como já sempre estavam. Tudo está continuamente vindo a ser si mesmo. O céu está continuamente se transformando e se transubstanciando em céu, a terra em terra, a água em água, o ar em ar, o fogo em fogo, enfim, cada ente está continuamente se tornando si mesmo. Só que este tornar-se si mesmo do humano não se dá sem o empenho e a graça da dinâmica da liberdade. É pelo empenho e pela graça da liberdade que o humano vem a ser o que ele é, ou seja, o que ele originaria e propriamente já era, numa palavra, vem a ser o seu poder-ser.

9. Aqui, a palavra destino, em alemão, Geschick-donde vem Geschichte, história -, não significa fatalidade (Schiksal), mas sim o reunir-se (cf. o prefixo "Ge") da dinâmica de um envio, de uma destinação que, uma vez assumida desta ou daquela maneira, se deslancha (Schicken = enviar, destinar). Fatalidade fala de uma coação obtusa e cega, que nos tranca e barra o caminho da viagem da vida. Destino, porém, diz justamente o contrário, pois acena para o envio do poder-ser que, uma vez assumido como o único necessário, faz deslanchar todo o caminho, transformando o inexorável e o inevitável em tarefa do empenho e da graça da própria liberdade. 
10. Nem é preciso dizer que, aqui, entendemos a expressão "vontade de poder" num sentido ontológico, que, em si, diz a vontade de poder-ser, e que, no seu sentido mais pleno e próprio, é muito mais do que a vontade de querer dominar, no sentido de querer explorar e oprimir. Este querer é, antes, uma de-cadência da vontade de poder, no sentido de não se dispor o bastante para o vigor de sempre de novo querer o poder-ser e, a partir daí, querer o querer do próprio querer, na dinâmica da plena autonomia e da plena responsabilização, por si, pelo outro e por tudo o mais.

11. A palavra alemã Dasein é traduzida normalmente como existência. Em Ser e Tempo, porém, Dasein designa o fundamento ontológico do ser-humano, ou seja, o fundo a partir do qual o humano se essencializa, se torna o humano, que é. Dasein diz o fundo do ser humano, a partir donde ele acontece e se constitui como humano. Diz, antes de tudo, esta possibilidade da liberdade, pela qual o ser humano acontece como a abertura do mundo, na disposição cordial de se responsabilizar por si e por tudo quanto há. Tal disposição da boa-vontade da liberdade diz, sempre de novo, em cada nova situação, em toda possibilidade e impossibilidade: eis-me aqui! Presente! Dasein diz, pois, presença, não como simples ocorrência de algo simplesmente dado, mas como intensidade, suavidade, radicalidade, transparência, propriedade do ser-simesmo, abrindo-se como a clareira, em que se clareia e se libera o sentido do ser de tudo quanto, de alguma maneira, é, em sua pregnância e plenitude.

\section{REFERÊNCIAS}

BUZZI, A. R. Filosofia para principiantes. Petrópolis, RJ: Vozes, 1998.

FOGEL, G. Da solidão perfeita - Escritos de filosofia. Petrópolis, RJ: Vozes, 1998.

HARADA, H. Coisas, velhas e novas - À margem da espiritualidade franciscana. Bragança Paulista, SP: Editora Universitária São Francisco/IFAN, 2006.

HEIDEGGER, M. Nietzsche II. Stuttgart: Neske, 1998.

LEÃO, E. C. Introdução a Agostinho de Hipona. In: Agostinho. A cidade de Deus, parte I. Petrópolis, RJ: Vozes, 1990.

MERTON, T. A via de Chuang Tzu. Petrópolis, RJ: Vozes, 2002.

RILKE, R. M. Cartas a um jovem poeta: A canção de amor e de morte do portaestandarte Cristóvão Rilke. São Paulo, SP: Globo, 2004.

ROMBACH, H. Strukturanthropologie - “Der menschliche Mensch”. Freiburg/ München: Alber, 1993. 
SILESIUS, Â. Il Pellegrino Cherubico. Torino: Ed. Paoline, 1989.

SCHUBACK, M. S. C.. O começo de Deus. Petrópolis, RJ: Vozes, 1998.

SCHUBACK, M. S. C. (Org.). Ensaios de filosofia-Homenagem a Emmanuel Carneiro Leão. Petrópolis, RJ: Vozes, 1999. 
